\title{
Puerarin increases the chemosensitivity of hepatocellular carcinoma cells
}

\author{
ZHEN WU ${ }^{1}$, JING WU ${ }^{2}$, PING FANG ${ }^{3}$ and SHIFENG KAN ${ }^{4}$ \\ Departments of ${ }^{1}$ Clinical Laboratory and ${ }^{2}$ Pharmacy, The Second Hospital of Shandong University, Jinan, \\ Shangdong 250033; ${ }^{3}$ Department of Blood Transfusion, Qianfoshan Hospital of Shandong, Jinan, Shangdong 250014; \\ ${ }^{4}$ Department of Clinical Laboratory, Qilu Hospital, Shandong University, Jinan, Shangdong 250012, P.R. China
}

Received March 28, 2017; Accepted June 29, 2017

DOI: $10.3892 / \mathrm{ol} .2017 .6524$

\begin{abstract}
The present study investigated the effect of puerarin $(\mathrm{Pu})$ on the sensitivity of HepG2 human hepatocellular carcinoma (HCC) cells to chemotherapeutic drugs to determine the possible mechanism. HepG2 cells were treated with different concentrations of $\mathrm{Pu}$ and cisplatin (CDDP), alone or in combination. MTT assay was used to determine the inhibitory effects of the different drugs on HepG2 cells. Cell morphology was observed by inverted microscopy. The expression of B-cell lymphoma 2 (Bcl-2) and Bax protein was measured by western blot analysis. $\mathrm{Pu}$ and CDDP, alone or in combination, inhibited the proliferation of HepG2 cells. The inhibitory effect of CDDP combined with Pu on HepG2 cells was significantly higher than that of the single drug treatments $(p<0.01)$. In addition, compared with the single drug groups, cellular morphology was significantly altered and the apoptotic rate of cells and the expression of Bax protein were significantly increased $(\mathrm{p}<0.01)$. However, the expression of Bcl-2 protein was significantly decreased $(\mathrm{p}<0.01)$ in the combined drug group. In conclusion, $\mathrm{Pu}$ can increase the sensitivity of HCC to chemotherapeutic drugs, enhance the inhibitory effect of chemotherapeutic drugs on cell proliferation and synergistically induce apoptosis of HepG2 cells. The mechanism is likely related to the upregulation of Bax protein and the downregulation of Bcl-2 protein.
\end{abstract}

\section{Introduction}

Hepatocellular carcinoma (HCC) is the fifth most common malignant tumor in the world and its incidence is increasing. It is the third most common cause of cancer-related death among malignant tumors (1), ranking second and sixth

Correspondence to: Dr Shifeng Kan, Department of Clinical Laboratory, Qilu Hospital, Shandong University, 115 West Wenhua Road, Jinan, Shangdong 250012, P.R. China

E-mail: kjs2sn@163.com

Key words: puerarin, cisplatin, human hepatocellular carcinoma cell line HepG2, chemosensitivity among tumor-related causes of death in males and females, respectively (2). Currently, surgery is the most common method of treatment of liver cancer. However, the clinical symptoms of liver cancer are not obvious and are often overlooked. When patients experience symptoms such as weight loss, jaundice, abdominal mass and liver pain, the vast majority have reached the advanced or terminal stage of the disease. Although radiotherapy and chemotherapy have certain effects, only $10 \%$ of patients are likely to undergo complete hepatectomy. While $90 \%$ of patients are treated with radiotherapy, chemotherapy, or radiofrequency ablation, it is difficult to achieve the expected clinical results because of low efficacy and high rate of severe side effects. Therefore, effective treatment of liver cancer is severely lacking $(3,4)$.

In traditional Chinese medicine, Chinese herbal medicines have many advantages. Their active ingredients generally have high efficiency and low toxicity. Scientists worldwide have paid increasing attention to Chinese herbal medicines because of their irreplaceable advantages. Studies have shown that Chinese herbal medicine has significant advantages for the prolongation of survival, prevention and treatment of liver cancer and metastasis (5). In recent years, with studies on the anticarcinogenic mechanisms of Chinese herbal medicine, more active ingredients have been extracted. Puerarin $(\mathrm{Pu})$ belongs to the group of isoflavone flycoside compounds and is extracted from the traditional Chinese medicine leguminous plants, Pueraria thomsonii Benth and Pueraria lobata (Willd.) Ohwi. It was reported that $\mathrm{Pu}$ has antitumor activity (6-8).

The aim of the present study was to investigate the effect of $\mathrm{Pu}$ on the sensitivity of HepG2 human HCC cells to chemotherapeutic drugs and its possible mechanism, to provide a foundation for the treatment of HCC.

\section{Materials and methods}

Reagents. Pu (Aladdin Reagent Co. Ltd., Shanghai, China); HepG2 cell line (Cell Bank of Chinese Academy of Sciences, Shanghai, China); Dulbecco's modified Eagle's medium (DMEM), fetal bovine serum (FBS) (HyClone Laboratories, Logan, UT, USA); primary rabbit polyclonal GAPDH antibody (dilution, 1:1,000; cat. no. 10494-1-AP), rabbit polyclonal 
Bax antibody (dilution, 1:500; cat. no. 50599-2-Ig), rabbit polyclonal Bcl-2 antibody (dilution, 1:500; cat. no. 12789-1-AP) and mouse monoclonal HRP-conjugated secondary antibody (dilution, 1:2,000; cat. no. HRP-66008) were all purchased from Sanying Biotechnology Co. Ltd. (Wuhan, Hubei, China). Cell lysis buffer, BCA protein concentration quantification kit, Annexin V-FITC apoptosis detection kit (all from Biyuntian Biotechnology Research Institute, Nantong, China); 3-(4,5-dimethylthiazol-2-yl)-2,5-diphenyltetrazolium bromide (MTT), dimethyl sulfoxide (DMSO) (Sigma, St. Louis, MO, USA).

Cell culture. HepG2 cells were cultured in an incubator at $37^{\circ} \mathrm{C}$ and $5 \% \mathrm{CO}_{2}$ in DMEM medium containing $100 \mathrm{U} / \mathrm{ml}$ penicillin, $100 \mu \mathrm{g} / \mathrm{ml}$ streptomycin and $10 \% \mathrm{FBS}$. When cells were in the logarithmic phase of growth, they were digested with trypsin and single cell suspensions were prepared. Cells were grouped and seeded in different culture plates or Petri dishes according to experimental needs.

MTT assay. Cells were divided into the experimental and control groups. HepG2 cells in the logarithmic growth phase were collected and seeded in 96-well plates at a concentration of $1 \times 10^{4} / \mathrm{ml}$, with $200 \mu \mathrm{l}$ per well. After $24 \mathrm{~h}$, the experimental group was divided into 12 subgroups according to different treatments: Four groups treated with $\mathrm{Pu}$ alone (final concentrations of 25,50,100 and $125 \mu \mathrm{M}$, respectively), four groups treated with cisplatin (CDDP) alone (final concentrations of $2.5,5,10$, and $20 \mu \mathrm{M}$, respectively) and four groups treated with the combined drugs (final concentrations of $25 \mu \mathrm{M} \mathrm{Pu}+2.5 \mu \mathrm{g} / \mathrm{ml}$ CDDP, $50 \mu \mathrm{M} \mathrm{Pu}+5 \mu \mathrm{g} / \mathrm{ml}$ CDDP, $100 \mu \mathrm{M} \mathrm{Pu}+10 \mu \mathrm{g} / \mathrm{ml} \mathrm{CDDP}$ and $125 \mu \mathrm{M} \mathrm{Pu}+20 \mu \mathrm{g} / \mathrm{ml}$ CDDP, respectively). Each condition was repeated five times. Cells in the control group were cultured in the same culture medium without treatment. After $48 \mathrm{~h}$, the culture medium was discarded and cells were washed three times with phosphate-buffered saline (PBS). The cells were then incubated with $100 \mu \mathrm{l}$ of MTT $(5 \mathrm{mg} / \mathrm{ml})$ for $4 \mathrm{~h}$ and $100 \mu \mathrm{l}$ of DMSO was added to each well with shaking in the dark for $10 \mathrm{~min}$. The absorbance value (OD) at $570 \mathrm{~nm}$ was measured using a microplate reader (Thermo Fisher Scientific, New York, NY, USA). The rate of inhibition was calculated according to the following formula: Inhibitory rate $(\%)=(\mathrm{OD}$ value of the control group - OD value of the experimental group/OD value of the control group) $\mathrm{x} 100 \%$.

Morphological observation. The cells were divided into four groups: The control group, Pu group $(100 \mu \mathrm{M})$, CDDP group $(10 \mu \mathrm{g} / \mathrm{ml})$ and $\mathrm{Pu}(100 \mu \mathrm{M})+\mathrm{CDDP}(10 \mu \mathrm{g} / \mathrm{ml})$ group. After the cells were treated accordingly, morphological changes were observed and recorded with an inverted microscope (AZ100; Nikon, Tokyo, Japan).

Analysis of apoptosis. According to the results of the MTT assay, cells were divided into four groups: The control group, Pu group $(100 \mu \mathrm{M})$, CDDP group $(10 \mu \mathrm{g} / \mathrm{ml})$ and $\mathrm{Pu}(100 \mu \mathrm{M})$ + CDDP $(10 \mu \mathrm{g} / \mathrm{ml})$ group. In the logarithmic growth phase, HepG2 cells were seeded in 6-well plates. After cells adhered, they were treated accordingly for $24 \mathrm{~h}$, washed three times with PBS, digested with trypsin and centrifuged.
Table I. The effects of Pu and CDDP on HepG2 cell proliferation (mean $\pm \mathrm{SD})$.

\begin{tabular}{lcc}
\hline \multicolumn{3}{c}{ Concentration } \\
\hline $\mathrm{Pu}(\mu \mathrm{M})$ & CDDP $(\mu \mathrm{g} / \mathrm{ml})$ & \\
\hline 0 & 0 & 0 \\
25 & 0 & $13.20^{\mathrm{a}}$ \\
50 & 0 & $27.95^{\mathrm{a}}$ \\
100 & 0 & $31.87^{\mathrm{a}}$ \\
125 & 0 & $46.91^{\mathrm{a}}$ \\
0 & 2.5 & $7.85^{\mathrm{a}}$ \\
0 & 5 & $17.35^{\mathrm{a}}$ \\
0 & 10 & $28.71^{\mathrm{a}}$ \\
0 & 20 & $39.29^{\mathrm{a}}$ \\
25 & 2.5 & $27.08^{\mathrm{a}, \mathrm{b}}$ \\
50 & 5 & $47.25^{\mathrm{a}, \mathrm{b}}$ \\
100 & 10 & $60.61^{\mathrm{a}, \mathrm{b}}$ \\
125 & 20 & $90.29^{\mathrm{a}, \mathrm{b}}$ \\
\hline
\end{tabular}

${ }^{\mathrm{a}} \mathrm{p}<0.01$ vs. the control group; ${ }^{\mathrm{b}} \mathrm{p}<0.01$ vs. the same dose of single drug group. $\mathrm{Pu}$, puerarin; CDDP, cisplatin.

All protocols were followed according to the instructions of the kit. Cells were resuspended in $0.3 \mathrm{ml}$ of binding buffer, followed by addition of $5 \mu \mathrm{l}$ of Annexin V and $5 \mu \mathrm{l}$ of PI. After incubation at room temperature for $15 \mathrm{~min}$ in the dark, $0.2 \mathrm{ml}$ of binding buffer was added to each sample. Apoptosis was detected by flow cytometry (Becton Dickinson, New York, NY, USA).

Western blot analysis. Cells were treated in the same manner as for morphological observation, harvested and lysed with lysis buffer. The supernatant was collected after centrifugation at high speed for $15 \mathrm{~min}$. The protein concentration was determined using a BCA kit. A total of $40 \mu \mathrm{g}$ of protein was used for SDS-PAGE and the wet transfer method was used for protein transfer to membranes. Membranes were blocked in $10 \%$ skim milk, and incubated with primary antibodies against Bcl-2, Bad and GAPDH $(1: 1,000)$ overnight at $4^{\circ} \mathrm{C}$. Next, secondary antibody $(1: 2,000)$ was added and membranes were incubated at room temperature for $2 \mathrm{~h}$. ECL was added to membranes, blots were developed in a dark room and images were scanned and recorded.

Statistical analysis. Data are presented as mean \pm standard deviation. Data were analyzed by SPSS 17.0 (IBM Corp., New York, NY, USA) using one-way ANOVA. $\mathrm{p}<0.05$ was considered statistically significant.

\section{Results}

The effect of Pu combined with CDDP on the proliferation of HepG2 cells. MTT assay was used to determine the effects of $\mathrm{Pu}$ and $\mathrm{CDDP}$, alone or in combination, on the proliferation of HepG2 cells (Table I). Pu and CDDP alone inhibited the proliferation of HepG2 cells in a concentration-dependent 
Control

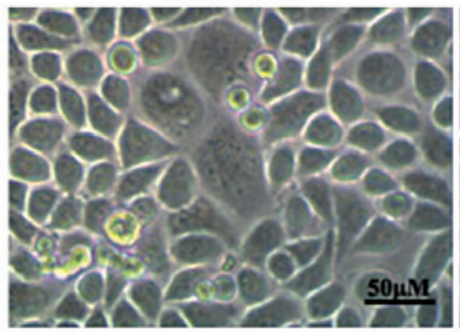

Pu

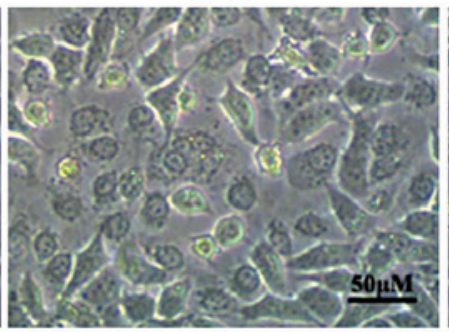

CDDP

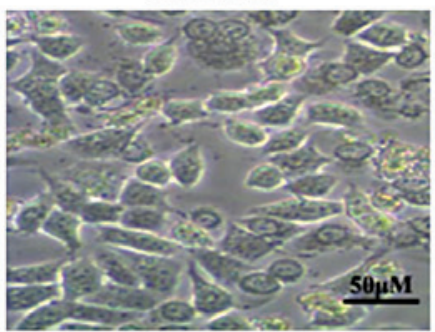

Pu+CDDP

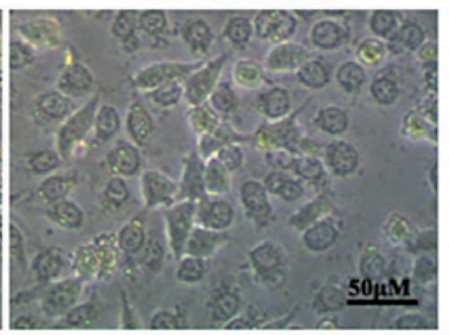

Figure 1. The effect of Pu combined with CDDP on the morphology of HepG2 cells. The morphological changes were observed after treatment with Pu, CDDP and $\mathrm{Pu}+\mathrm{CDDP}$ for $48 \mathrm{~h}$. Cell morphology in the treatment groups changed markedly, especially in the combined drug group. Morphological changes included cell shrinkage, reduction of cell adherence, decrease in cell number, and increase in the number of dead cells. Pu, puerarin; CDDP, cisplatin.

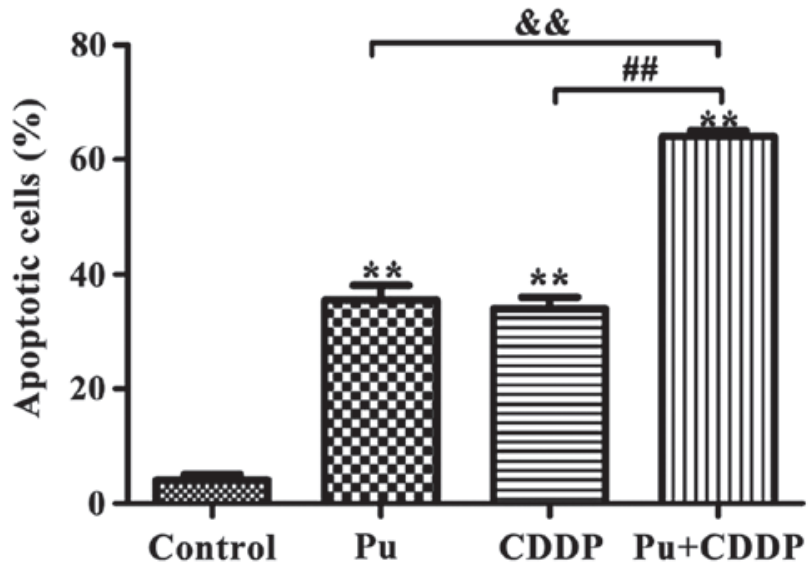

Figure 2. Detection of cell apoptosis in different treatment groups by flow cytometry. ${ }^{* *} \mathrm{p}<0.01$ vs. the control group; ${ }^{\# \#} \mathrm{p}<0.01$ the combined treatment group vs. the CDDP alone group; ${ }^{\& \&} \mathrm{p}<0.01$ the combined treatment group vs. the $\mathrm{Pu}$ alone group. CDDP, cisplatin; Pu, puerarin.

manner. The inhibitory effect increased with increasing drug concentration. The inhibitory effect of $\mathrm{Pu}$ and CDDP in combination on the proliferation of HepG2 cells was significantly higher than that of the corresponding single drug treatments ( $\mathrm{p}<0.01)$. The doses of $100 \mu \mathrm{M} \mathrm{Pu}$ and $10 \mu \mathrm{g} / \mathrm{ml} \mathrm{CDDP}$ and $100 \mu \mathrm{M} \mathrm{Pu}+10 \mu \mathrm{g} / \mathrm{ml}$ CDDP were used in the single drug groups and combined drug group, respectively, for subsequent experiments.

The effect of Pu combined with CDDP on the morphology of HepG2 cells. Except for the control group, cells in the treatment groups were treated with $\mathrm{Pu}(100 \mu \mathrm{M}), \mathrm{CDDP}(10 \mu \mathrm{g} / \mathrm{ml})$ and $\mathrm{Pu}(100 \mu \mathrm{M})+\mathrm{CDDP}(10 \mu \mathrm{g} / \mathrm{ml})$, respectively (Fig. 1). After $48 \mathrm{~h}$, cell morphology in the treatment groups changed significantly compared with the control group, especially in the combined treatment group. These changes included cell shrinkage, reduction of cell adherence, decrease in cell number and increase in the number of dead cells.

The effect of $\mathrm{Pu}$ combined with CDDP on apoptotic rate of HepG2 cells. According to the results of the MTT assay, $100 \mu \mathrm{M} \mathrm{Pu}$ and $10 \mu \mathrm{g} / \mathrm{ml} \mathrm{CDDP}$ were selected to investigate whether $\mathrm{Pu}$ enhanced the sensitivity of HepG2 cells to the chemotherapeutic drug, CDDP. As shown in Fig. 2, the apoptotic rates in the control, $\mathrm{Pu}, \mathrm{CDDP}$ and combined drug groups were $3.92 \pm 0.42,35.74 \pm 4.18,32.93 \pm 3.68$ and
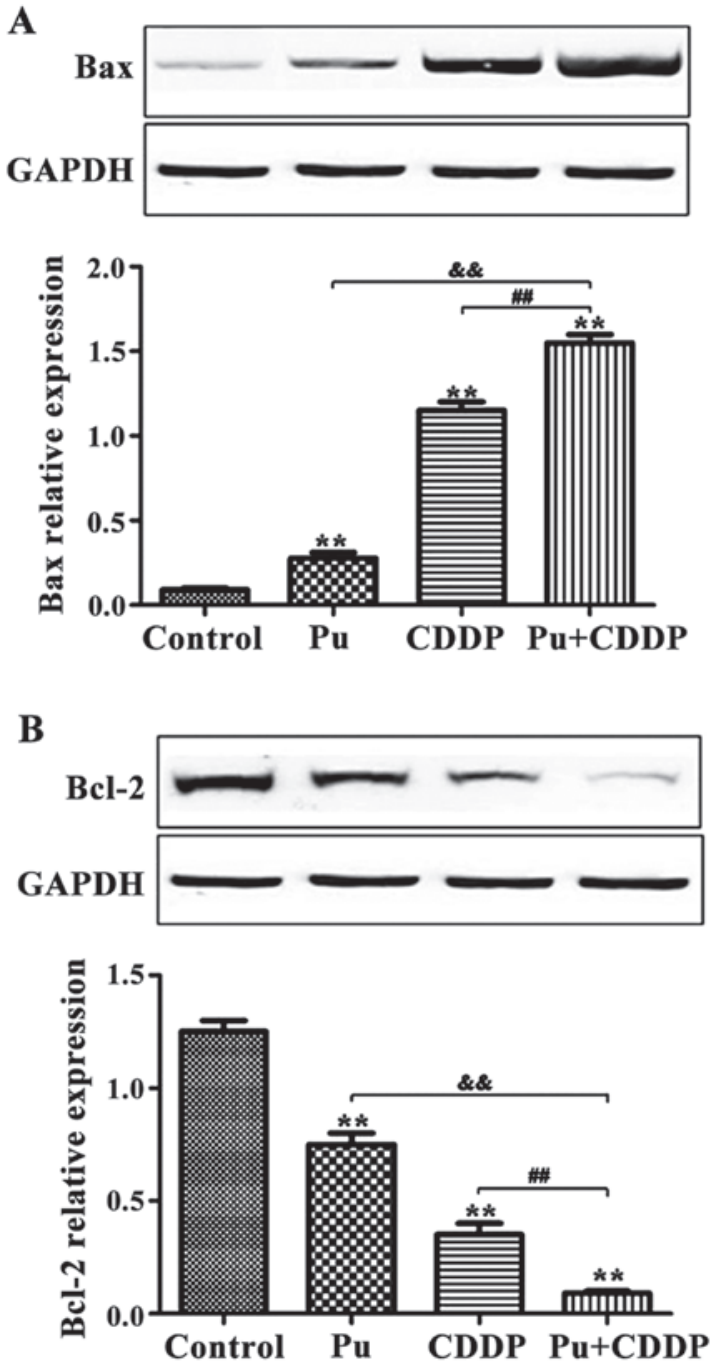

Figure 3. Determination of apoptosis-related protein expression by western blot analysis. (A) Bax protein expression; (B) Bcl-2 protein expression; ${ }^{* *} \mathrm{p}<0.01$ vs. the control group; ${ }^{\# \#} \mathrm{p}<0.01$ the combined treatment group vs. the CDDP alone group; ${ }^{\& \&} \mathrm{p}<0.01$ the combined treatment group vs. the $\mathrm{Pu}$ alone group. CDDP, cisplatin, $\mathrm{Pu}$, puerarin.

$62.03 \pm 7.65 \%$, respectively. Compared with Pu or CDDP alone, the apoptotic rate of the combination group was significantly increased $(\mathrm{p}<0.01)$.

The effect of $P u$ combined with CDDP on the expression of apoptosis-related proteins in HepG2 cells. Western blot 
analysis results are shown in Fig. 3. Compared with the control group, $100 \mu \mathrm{M} \mathrm{Pu}$ or $10 \mu \mathrm{g} / \mathrm{ml}$ CDDP alone induced Bax protein expression in HepG2 cells. In contrast, $\mathrm{Pu}$ and CDDP in combination significantly increased Bax protein expression $(\mathrm{p}<0.01)$. The expression of Bcl-2 protein in HepG2 cells was downregulated by $100 \mu \mathrm{M}$ Pu or $10 \mu \mathrm{g} / \mathrm{ml} \mathrm{CDDP}$ alone and the inhibitory effect was more significant when $\mathrm{Pu}$ was combined with CDDP $(\mathrm{p}<0.01)$.

\section{Discussion}

HCC is a common malignant tumor and has a high mortality rate because of the lack of effective early diagnosis and therapy (9). Liver cancer has various causes, among which chronic liver inflammation caused by excessive drinking, viral hepatitis and non-alcoholic liver fatty degeneration is a key factor (10). As a method of discovering new drugs, extracting natural compounds from Chinese herbal medicines has been increasingly accepted and employed. This not only results in acquiring better active components, but also better control of the quality of Chinese medicines. Therefore, extracting chemically active substances from traditional Chinese medicine has been an area of strong interest in antitumor studies. $\mathrm{Pu}$ belongs to the group of isoflavone flycoside compounds and is one of the main active ingredients of leguminous plants. It was approved for clinical use by the Ministry of Health in 1993. Initially, it was primarily used for the treatment of cerebrovascular disease and as the result of further study, $\mathrm{Pu}$ was found to have a certain effect on cancer treatment (11).

Bcl-2 has been shown to inhibit apoptosis (12-14) and it plays an important role in the mechanism of apoptosis. It can protect cells from various causes of death, and improve cell survival, thereby increasing the number of cells. In some tumor cells, when Bcl-2 gene expression is upregulated, tumor cells are prevented from dying, or have their survival prolonged (15), suggesting that the $\mathrm{Bcl}-2$ gene is closely related to the tumor. In contrast, Bax can promote apoptosis. Bcl-2 and Bax belong to the same gene family, and Bax binds the Bcl-2 protein, which can not only inhibit Bcl-2-mediated apoptosis, but also directly promote cell apoptosis $(16,17)$. The $\mathrm{BH} 1$ and $\mathrm{BH} 2$ domains in the coding region of the Bax gene are highly homologous to the Bcl-2 gene, which are important components involved in the regulation of apoptosis. When Bcl-2 forms a homodimer, it plays a role in inhibiting apoptosis. When Bax protein expression increases and aggregates with Bcl-2 forming a dimer, or Bax protein itself homodimerizes, it plays a role in promoting apoptosis (11).

In this study, we found that $\mathrm{Pu}$ or CDDP alone inhibited HepG2 cell proliferation and induced apoptosis. The inhibitory effect on HepG2 proliferation was significantly greater in the $\mathrm{Pu}$ and $\mathrm{CDDP}$ combination group compared with the same doses in the single drug groups. The morphological changes such as shrinkage, decreased cell adherence, reduced cell number and increased cell death number were more obvious in the combined drug group. The results of flow cytometry using Annexin V-PI double staining showed that the combination of the two drugs resulted in a significantly higher rate of apoptosis compared with the single drug groups. Western blot analysis showed that compared with the control group, $\mathrm{Pu}$ or CDDP alone induced the expression of Bax protein in HepG2 cells.
However, the expression of Bax protein was more significant when $\mathrm{Pu}$ and CDDP were used in combination. $\mathrm{Pu}$ or CDDP alone downregulated the expression of $\mathrm{Bcl}-2$ protein in $\mathrm{HepG} 2$ cells. The inhibitory effect on the expression of $\mathrm{Bcl}-2$ protein was significant in the $\mathrm{Pu}$ and CDDP combination group compared with the same doses in the single drug groups. The study by $\mathrm{Xi}$ et al (18) indicated that some active ingredients of traditional Chinese medicines can upregulate Bax expression by downregulating Bcl-2 expression in tumor cells, thereby inducing apoptosis of tumor cells. For example, carnosol was shown to upregulate Bax expression and downregulate $\mathrm{Bcl}-2$ expression by $34-53 \%$. Neri et al (19) showed that the expression of Bax protein was upregulated and the expression of Bcl-2 was downregulated when epithelial tumor cells of the digestive tract were abnormal, which was likely related to the formation of digestive tract tumors. Their results were similar to those of our study, further confirming that $\mathrm{Pu}$ increases the apoptosis of liver cancer cells, likely by upregulating Bax and downregulating $\mathrm{Bcl}-2$ protein expression.

In conclusion, this study demonstrated that $\mathrm{Pu}$ can enhance the sensitivity of HepG2 cells to chemotherapeutic drugs and induce the apoptosis of HepG2 cells. The mechanism is likely related to the upregulation of Bax and downregulation of Bcl-2 protein expression.

\section{References}

1. Bruix J, Reig M and Sherman M: Evidence-based diagnosis, staging, and treatment of patients with hepatocellular carcinoma. Gastroenterology 150: 835-853, 2016.

2. Sileri P, D'Ugo S, Benavoli D, Stolfi VM, Palmieri G, Mele A and Gaspari AL: Metachronous splenic metastasis from colonic carcinoma five-years after surgery: A case report and literature review. South Med J 102: 733-735, 2009.

3. Zhang MQ, Lin X, Li Y and Lu S: Irinotecan as a second-line chemotherapy for small cell lung cancer: A systemic analysis. Asian Pac J Cancer Prev 16: 1993-1995, 2015.

4. Phelps MA and Sparreboom A: Irinotecan pharmacogenetics: A finished puzzle? J Clin Oncol 32: 2287-2289, 2014.

5. Takeno S, Noguchi T, Kikuchi R, Uchida Y, Yokoyama S and Müller W: Prognostic value of cyclin B1 in patients with esophageal squamous cell carcinoma. Cancer 94: 2874-2881, 2002.

6. Wei SY, Chen Y and Xu XY: Progress on the pharmacological research of puerarin: A review. Chin J Nat Med 12: 407-414, 2014.

7. Maji AK, Pandit S, Banerji P and Banerjee D: Pueraria tuberosa: A review on its phytochemical and therapeutic potential. Nat Prod Res 28: 2111-2127, 2014.

8. Wang J, Yang ZR, Guo XF, Song J, Zhang JX, Wang J and Dong WG: Synergistic effects of puerarin combined with 5-fluorouracil on esophageal cancer. Mol Med Rep 10: 2535-2541, 2014.

9. Tang W, Zhu J, Su S, Wu W, Liu Q, Su F and Yu F: MiR-27 as a prognostic marker for breast cancer progression and patient survival. PLoS One 7: e51702, 2012.

10. Nakagawa H, Umemura A, Taniguchi K, Font-Burgada J, Dhar D, Ogata H, Zhong Z, Valasek MA, Seki E, Hidalgo J, et al: ER stress cooperates with hypernutrition to trigger TNF-dependent spontaneous HCC development. Cancer Cell 26: 331-343, 2014.

11. le Sage $C$ and Agami R: Immense promises for tiny molecules: Uncovering miRNA functions. Cell Cycle 5: 1415-1421, 2006.

12. Croker BA, O'Donnell JA, Nowell CJ, Metcalf D, Dewson G, Campbell KJ, Rogers KL, Hu Y, Smyth GK, Zhang JG, et al: Fas-mediated neutrophil apoptosis is accelerated by Bid, Bak, and Bax and inhibited by Bcl-2 and Mcl-1. Proc Natl Acad Sci USA 108: 13135-13140, 2011.

13. Zhai D, Jin C, Huang Z, Satterthwait AC and Reed JC: Differential regulation of Bax and Bak by anti-apoptotic Bcl-2 family proteins Bcl-B and Mcl-1. J Biol Chem 283: 9580-9586, 2008 . 
14. Krishna S, Low IC and Pervaiz S: Regulation of mitochondrial metabolism: Yet another facet in the biology of the oncoprotein Bcl-2. Biochem J 435: 545-551, 2011.

15. Hwang HW and Mendell JT: MicroRNAs in cell proliferation, cell death, and tumorigenesis. Br J Cancer 96 (Suppl): R40-R44, 2007.

16. Zhang J, Du Y, Wu C, Ren X, Ti X, Shi J, Zhao F and Yin H: Curcumin promotes apoptosis in human lung adenocarcinoma cells through miR-186* signaling pathway. Oncol Rep 24: 1217-1223, 2010

17. Bartel DP: MicroRNAs: Target recognition and regulatory functions. Cell 136: 215-233, 2009.
18. Xi S, Dyer KF, Kimak M, Zhang Q, Gooding WE, Chaillet JR, Chai RL, Ferrell RE, Zamboni B, Hunt J, et al: Decreased STAT1 expression by promoter methylation in squamous cell carcinogenesis. J Natl Cancer Inst 98: 181-189, 2006.

19. Neri M, Betta P, Marroni P, Filiberti R, Cafferata M, Mereu C, Ivaldi G, Montanaro F, Puntoni R and Paganuzzi M: Serum anti-p53 autoantibodies in pleural malignant mesothelioma, lung cancer and non-neoplastic lung diseases. Lung Cancer 39: 165-172, 2003. 